\title{
SEEING THE AGREEMENT OF THE RESIDENTS IN FILLING EMPTY SPACE IN THE SETTLEMENT
}

\author{
Erza Rahma Hajaty, Rona Fika Jamila, Ika Riski Laela Wati \\ Architecture, Mercu Buana University, Indonesia \\ e-mail: erza.rahma@mercubuana.ac.id
}

\begin{abstract}
Land availability is increasingly limited, so it is not surprising that land prices are getting more expensive. However, behind the high cost of land, there is a lot of space, especially in settlements, in the form of vacant land, buildings, ready-to-build land and built-up land that is not utilized or stalled. There are houses in settlements that are purchased only for investment so that they are not used or occupied by the owner, vacant land under a network of sutets, and land in the form of lots ready to build in unsold housing. This condition is deplorable given the high price of land and the very high needs of the community for land, especially for housing, social Space and as a place of business. Therefore, this research is to see how the occupants agree to fill the Space in the settlement, using qualitative methods. The results showed that most residents agree that empty spaces in settlements should not be left open for too long but can be used for valuable things while maintaining public interests, not harming others, not disturbing others, positive activities. And keep the environment clean. The use of Space in settlements, both formal and nonformal by residents of the premises, is a place to raise fish, place animal cages, plant fruit and vegetable gardens, park vehicles, play areas for children, place temporary leaf trash, sports fields and night markets.
\end{abstract}

Keywords: Deal, Filling Space, Empty Space, Settlements

\section{INTRODUCTION}

The large-scale housing development is carried out to meet community needs for housing. This is in line with the program of the Ministry of Public Works and Public Housing (PUPR) through the One Million Houses program, which until October 14 2019 , has reached 1,002,317 units, which are divided into 706,440 units of lowincome people (MBR) (70\%). And non-MBR as many as 295,877 units (30\%). However, the expected goals do not always match the reality, where investors buy land or buildings to invest in and not live in. Therefore, in some formal settlements, there are empty spaces such as land or buildings that are seen to be left unattended 
and unkempt by their owners, which has resulted in the environmental conditions of the settlements, which have gradually become slum with a land filled with grass and buildings that are getting worse. This is, of course, contrary to the original goal of large-scale settlement development to meet community housing needs. Not only in formal residential housing but also in many empty spaces in several informal housing environments or villages, which are then used for certain activities such as business premises, children's play, hangouts, etc.

Based on the above conditions, with the large number of empty spaces in settlements, either land or buildings, which are then filled for various activities, it shows that residents and residents need this open space. However, do the residents around the Space agree with the form of use of the empty spaces, do they feel disturbed, or are they sound, and how do the residents around the open Space behave towards the state of their use. Therefore, through this research, he wants to see and find out how the occupants agree to fill empty spaces in the settlement, the occupants' attitudes towards the use of open space, and how residents or users fill these empty spaces, using qualitative methods.

This study is helpful to determine the primary needs of residents for Space in settlements and their agreement and attitudes towards the use of space in the territory. The results of this study are expected to be a guideline for developers to design empty spaces in settlements as functional spaces for residents either temporarily or permanently. In addition, it can serve as a guideline for the government to make policies on empty spaces in settlements based on occupant agreements so that open spaces, especially land or buildings, do not stand idle for too long but can be more beneficial, especially for the surrounding residents.

Therefore, through this research, it is to find out how residents agree to fill empty spaces in the settlement? And how do residents and residents fill the open spaces in the payment? This is to find out how the residents agree to fill empty spaces in the settlement, including the occupants' attitudes towards the existence of open space and its use. This is to find out how residents around the Space, residents and residents outside the study area fill the empty spaces in the settlement.

\section{THEORY/ RESEARCH METHODS}

\section{Seeing Agreement}

Sengke \& Mustikawati (2019) explain that seeing is understood as a transaction between humans and architecture that involves the process of understanding and experiencing Space, where catching activities can be done either in a static or dynamic position, which creates a difference in how to experience and understand Space. The opinion of Sengke and Mustikawati can be understood that when seeing is not only knowing information obtained from sight, but also through the process of "understanding" in mind. According to Shea \& Ceprano (2017), their article explains that understanding is a very complex activity that requires active thinking 
and assimilation between messages and interpretation, analysis, evaluation, and synthesis that occur synchronously and generatively. Meanwhile, according to Helmstad (1999), understanding is as (i) acceptance of new knowledge either through observation or information, (ii) the acquisition of desired knowledge through deliberate activity completion, and (iii) realization of new truths based on experience and interpretation of experience. Therefore, based on some of the above meanings, it can be concluded that seeing is a process of understanding obtained through active thinking, both from the experience of observation and the information obtained.

According to Atmodiwirjo \& Yatmo (2018), he explains seeing interiority, namely as a relational construction that occurs between the user and the environment, where the form of the relationship occurs between the structure of responses or subjective experiences with physical Space. Then Juhani Pallasma (2012) explains between the oral Space versus the visual Space, where humans are not always dominated by sight; the view only gradually replaces hearing dominance. He also added that the anthropological literature describes a variety of cultures in which the senses of smell, taste and personal touch continue to have collective importance in behaviour and communication. The opinion of Atmodiwirjo \& Yatmo shows that seeing Space is not only seeing Space physically but in it; there is a subjective human experience that needs to be known and understood. Therefore, this is in line with Sengke \& Mustikawati (2019) thoughts that seeing is a process that involves understanding. This is also indirectly in line with Pallasma's opinion, which states that seeing involves the human senses, which does not only affect the visual senses but with other reasons at play, namely the sense of hearing, which functions to absorb speech information, then taste, which involves subjective thinking to understand data from the feelings. Visions, as well as speech, were received. Then also, Luck (2014), in his article Seeing Architecture in Action, explains how to see action in describing the aesthetic experience of Space and form with imagination, for a moment and having a representation that is presented. Luck's opinion is also in line with the above thought that it can be understood directly that there is a connection between experience and imagination, which also experiences a process of understanding in the mind which can then be presented in different forms as a result of learning.

Therefore, based on these definitions, this study aims to find out, find something and then understand the form of occupant agreement on the use of free space. The state of the contract will later be known based on the experience of researchers seeing the benefit of Space in settlements physically, then physically understanding the experiences of residents and users of open spaces in settlements which are then read and re-understood subjectively occupants' attitudes and agreements that occur.

Agree is agreeing and agreeing, while the agreement is about blending. Hoffner \& Field (2005) describes the process of an agreement that can be increased into an agreement; then, it can be further increased into a legal bond, namely in the form of a legal contract. List (2002) describes two agreement concepts: agreement at a substantive level and agreement at a meta-level. The difference between the two agreements is that the agreement at the meta-level agreement is obtained through a 
deliberation process to resolve conflicts between individuals with different preferences. Whereas at the substantive level, it does not deal with choices for individual options, but with a series of judgments on a whole set of propositions that are connected logically, so that agreement at the substantive level is likely to be more challenging to achieve but more realistic. Winter and Kamau's (2019) research on the Model Clauses for Mutually Agreed Terms on Access to Genetic Resources and Benefit Sharing explains how the negotiation process for an agreement on access to specific resources requires a fair and appropriate term as a form of a particular model agreement, which is not too restrictive but serves as a full completion document to provide confidence to the agreeing parties. Through his writing, it can be understood that in the agreement, what is meant is the existence of a bargaining process in the form of negotiations; negotiations can provide benefits to the parties who agree by using specific evidence to legalize it. So based on some of the definitions and opinions above, it can be understood that an agreement is a union of several opinions or views and the existence of a negotiation process so that an agreement occurs and then it can be legalized.

So in this study, the agreement is the agreement of the residents on how to fill the Space in the settlement. However, when this agreement is linked or preceded by the word "to see", it can be understood that "seeing the occupant's agreement" can be understood that this agreement is still seen so that it cannot be said to fully agree on how to fill in the space in the settlement. As explained above, witnessing the occupant's agreement is knowing, finding something and then understanding the form of contract in the form of a good attitude of understanding, feelings and expectations of residents regarding the use of Space. The state of the agreement will be known based on the experience of researchers seeing the benefit of Space in the settlement physically, then non-physically understanding the attitudes of the residents, both the consent, hopes and feelings of the occupants towards empty spaces in the settlement, which is then read and understood again.

\section{Empty Space and Settlement}

Stanek, in his book Henry Lefebvre on Space (2011), explains his understanding of Lefebvre's theory of Space, namely Space developed through three things, namely (i) the process of producing Space, (ii) socially productive Space, (iii) contra, conflict and politics in the space production process. Stanek also describes the relationship between space moments that connect elements that have been separated and replaced with apparent differences as a substitute for abstract Space. The opinion of Lefebvre expressed by Stanek can be understood that there are abstract spaces formed by social activities located between the functions of the main activities of Space so that a conceptual space that initially does not have clear boundaries and is created accidentally due to social activities can then become a space given clear boundaries as a link between the various functions of the main activities. 
Regarding activities in Space, Gehl (2012) divides activities in outdoor Space into three types, namely (i) Necessary activities, namely compulsory activities such as school, work, shopping, carrying out tasks, waiting for someone, (ii) Optional activities, namely most of them are recreational activities such as walking, breathing fresh air, sitting and standing enjoying life, and (iii) Social activities are activities that depend on the existence of other people in public spaces, such as children playing, greeting and chatting, various types of communal activities, and also seeing and listening to other people.

Regarding Space, Cheon \& Su (2018), in their article entitled The Value of Empty Space for Design explains that treating Space that focuses on minimalism is Space as a first-class object that deserves respect and represents, both visible and unseen. Seen. He also explained that all types of Space (such as workplaces, second homes and third places, such as libraries, cafes) are all places that can be used for interaction that contain "other spaces", namely spaces that are often neglected. He exemplified that the other room was like a dusty corner. The results of Cheon \& Su's research show that in each type of Space, it is possible to have another room, either visible or hidden, to become another room that is neglected.

Utilization of Space or activities carried out in Space. Therefore, based on the above opinions, the Space referred to in this study is a space in the form of physical Space, namely in the form of inner and outer space, either bounded by walls or not limited by borders, both areas that are initially abstract and are not. It has a clear function but is then used for specific activities and space that has a clear position but is not used according to its operation (it can be empty land, vacant land ready to build or built-in land). Besides that, the open space can also be in the form of other areas in the main room (such as the remaining land on the side of the road or the corner of the street, the Space formed above the ditch, etc. Filling the Space referred to in this research is a form of use or methods).

Housing is a collection of houses as part of a settlement, both urban and rural, equipped with general infrastructure, facilities, and utilities to fulfil a livable place. Settlements are part of a residential environment that consists of more than one housing unit with infrastructure, facilities, public utilities, and other supporting activities in urban or rural areas. Akcabozan \& Demir (2015) conducted a comparison between formal and informal housing in Istanbul, namely (i) formal housing has easy access, buildings and the environment are the results of design, using technology, the existence of arrangements for a healthy and safe environment and environment, spaces are not interconnected and separated, whereas (ii) informal housing has difficult access, buildings and the environment are not the result of design, do not use technology, there is no regulation in their environment, an environment that is less healthy and less secure, mutually exclusive spacesconnected and converging. Soyinka and Siu (2017) The types and nature of informal settlements identified in Hong Kong are related to scattered settlements, namely the existence of pockets of informal settlements, road structures (which are slum), lack of infrastructure availability, and the socio-economic characteristics of settlements (more for income earners). Low). This research is essential to carry out in formal and informal settlements so that complete data will be obtained, and it will also be known whether there are differences or even similarities in tenant agreements and 
occupants' attitudes towards the use of empty spaces in formal and informal settlements and whether they have similarities. Or differences in how to fill open spaces in formal and informal settlements.

\section{Methods}

Empty in settlements and the attitude of the occupants towards the use of these vacant spaces. The research design approach chosen is qualitative research, which is a method for exploring and understanding the meaning of several individuals or groups of people involving questions and procedures, collecting specific data from participants, analyzing data inductively, and interpreting the importance of the data (Creswell 2016). The data collection method was carried out by direct observation at the location, and interviews were carried out on adult residents informal settlements, namely Bukit Golf, Bogor Regency and informal housing, namely in the territory of Ciketik Udik village, Bantar Gebang, Bekasi, so that the occupants' agreement would be known in filling the spaces. The form of contract will be known based on the experience of researchers seeing the use of Space in settlements physically, then non-physically understanding the attitudes of residents, both the consent, hopes and feelings of residents towards open spaces in the settlement, which are then read and understood again to residents who are around empty spaces in the colony, to residents and residents who use the open Space and to environmental managers.

\section{RESULT AND DISCUSSION}

Bukit Golf Formal Settlement is located in Gunung Putri District, Bogor Regency. This settlement was founded in 2004 by PT. Cantika Kusuma's work. This settlement consists of several clusters, namely the Arcadia, Orchid, Riverside, Lavender, Golf Boulevard, Boulevard Terrace and Golf Side clusters. The Arcadia and Lavender clusters are medium-sized housing, while the Orchid, Riverside, Golf Boulevard, Boulevard Terrace, and Golf Side clusters are the middle to upper-class housing types. In this case, the Arcadia 5 and Orchid Clusters are the research areas. In the Bukit Golf settlement, there is ready-to-build land consisting of vacant lots (especially in the upper-middle cluster), empty buildings and yards, open spaces under the sunset lines, empty fields, empty spaces on sure sides of the building or park.

The informal settlement of Kampung Ciketing Udik is located in Bantar Gebang sub-district, Bekasi City. Kampung Ciketing Udik is one of the sub-districts in the Bantar Gebang sub-district, where the inhabitants are still indigenous even though they mingle with newcomers. In this settlement, there are still empty spaces in the form of empty buildings, empty land or empty gardens. 


\section{Empty Space in Settlements}

In the first research area, namely the Arcadia cluster, there are empty spaces left open by both the developer and the owner, as well as those that residents and residents have used. These empty spaces consist of (i) Plots ready to build, (ii) Residential buildings and yards, (iii) fields, (iv)Vacant land under the Sutet Lines (very high voltage power lines). The informal settlement of Kampung Ciketing Udik is located in Bantar Gebang sub-district, Bekasi City. In the two settlements, there are still empty spaces in empty buildings, empty land, or empty land gardens.
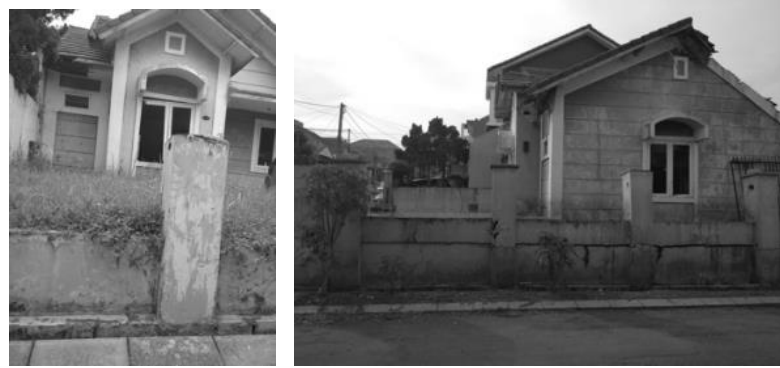

Figure 1. An empty house in Arcadia 5 Arcadia cluster Source: field survey, 2021

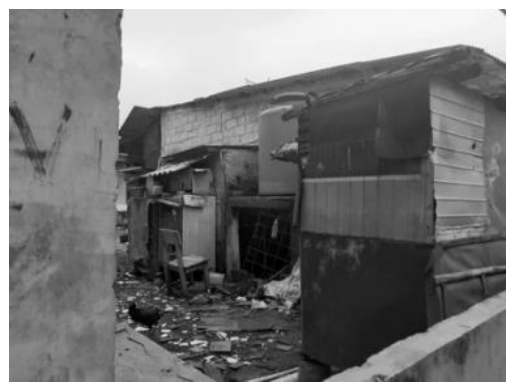

Figure 2. Empty house in kampung Ciketing Udik Source: field survey, 2021

\section{Resident Agreement on Filling Empty Space in the Settlement}

\section{The attitude of residents towards empty spaces that have not been used informal settlements}

The occupant's attitude shows whether the occupants agree or object to the existence of a space that is left empty or not used. In addition, the residents' perspective also offers the residents' feelings about the open spaces around them. The conclusion of some of the tenants 'attitudes will show the form of the residents' agreement. The interview results show that most of the respondents disagreed if the Space was left empty, as one of the residents said, "it would be a shame if it were useless". Then some residents also expressed their feelings if the Space was left untreated, "scary if not maintained". Besides that, some residents also disagreed with the existence of Space and felt disturbed, as one of the residents said it was "quite disturbing for fear of becoming a nest of reptiles". 
The following is the occupant's attitude which shows the occupant's agreement on the existence of Space in the settlement:

Table 1. The residents agree on the presence of Space

\begin{tabular}{|c|c|c|}
\hline Residents & Statement of Attitude & $\begin{array}{l}\text { Consensus on the fact } \\
\text { of Space }\end{array}$ \\
\hline 1 & "It's a shame if it's useless." & Agree if used \\
\hline 2 & "It's pretty annoying for fear of becoming. & $\begin{array}{l}\text { Disagree because it is } \\
\text { disturbed }\end{array}$ \\
\hline 3 & "Less comfortable" & $\begin{array}{l}\text { Disagree because it's } \\
\text { uncomfortable }\end{array}$ \\
\hline 4 & $\begin{array}{l}\text { If you can make the best use of the available } \\
\text { space }\end{array}$ & Agree if used \\
\hline 5 & $\begin{array}{l}\text { "It is beneficial; it can be used as advice for } \\
\text { community gatherings, green land, a place to } \\
\text { play, sports facilities ..." }\end{array}$ & Agree if used \\
\hline 6 & "Not clean enough." & $\begin{array}{l}\text { Disagree because it's } \\
\text { uncomfortable }\end{array}$ \\
\hline 7 & "Good for keeping the air clean." & Agreed \\
\hline 8 & $\begin{array}{l}\text { "Better to stay awake or be cared for by the } \\
\text { owner/environmentalist... if you don't worry } \\
\text { about snakes, lizards, rats ..." }\end{array}$ & Agree if maintained \\
\hline 9 & "Neglected" & Agree if maintained \\
\hline 10 & "There should be" & Agreed \\
\hline 11 & $\begin{array}{l}\text { "... many benefits if used ..., if neglected could } \\
\text { potentially become a nest for wild animals ..." }\end{array}$ & Agree if used \\
\hline 12 & "Must be used as well as possible." & Agree if used \\
\hline 13 & "Scary if not treated." & $\begin{array}{l}\text { I disagree because it is } \\
\text { not maintained } \\
\text { Disagree }\end{array}$ \\
\hline 14 & "Too bad" & Agree if used \\
\hline 15 & "Well utilized" & Agree if used \\
\hline 16 & $\begin{array}{l}\text { "Needed for catchment areas ... for productive } \\
\text { land." }\end{array}$ & \\
\hline
\end{tabular}

The attitude of residents of formal housing towards Space used for certain activities shows whether the occupants agree or object to the existence of Space that has been used either permanently or routinely or not permanently or at any time. In addition, the attitude of the residents also shows the residents' feelings about the empty spaces that have been used around them, so that it will show the form of agreement of the residents. Based on the results of the interview, it offers that most respondents agree that Space is used for:

1. Public interest

2. Don't harm other people 
3. Don't disturb other people

4. Positive activities

5. Not dirty

Occupants' expectations of Space informal settlements show the occupant's agreement whether the occupants want the Space to be used or not. Most of the residents expect that the Space around their house can be used for certain activities, as one occupant said, "so that there is a use-value, it's a shame if it is left empty it's useless". This sentence shows that the occupants want the Space not to be "left" empty, useless. The word 'left' can be understood that the Space does not get attention, is put aside and seems to be forgotten by its owner and the surrounding residents. In contrast, on the other hand, Space has excellent potential to be beneficial to its surroundings. So the occupant hopes that the Space will get attention and can be used for valuable things. Besides that, some residents do not want to take advantage of the space around them, as one occupant said, "not for a pandemic." This expression can be understood that the occupants have a desire for the Space to be utilized. However, because there is still a pandemic, they have concerns over the impact of the use of Space. Likewise, with the expression of one of the other residents, "do not want to take advantage of it because there are many dense bushes". The term can also be understood as disagreeing but for some reason, so that if the excuse of "many thickets" can be removed, it can lead to agreement and hope that the empty Space can be used ". The following are some agreements in the form of residents' hopes and desires for Space:

Table 2. The resident agreements in filling Space in settlements Source: Researcher, 2021

\begin{tabular}{|c|c|c|}
\hline Residents & Expectations/wishes of residents & $\begin{array}{l}\text { Agreement for } \\
\text { utilization }\end{array}$ \\
\hline 1 & $\begin{array}{l}\text { "To be useful and not become a den of animals or } \\
\text { shrubs." }\end{array}$ & Agree if used \\
\hline 2 & "For sports or children's play." & $\begin{array}{l}\text { Disagree because it } \\
\text { is disturbed }\end{array}$ \\
\hline 3 & "Not at the time of this pandemic." & $\begin{array}{l}\text { Disagree because } \\
\text { it's uncomfortable }\end{array}$ \\
\hline 4 & $\begin{array}{l}\text { "So that there is a use-value, it's a shame if you } \\
\text { leave it blank; it's useless. }\end{array}$ & Agree if used \\
\hline 5 & $\begin{array}{l}\text { "For activities of all residents, such as sports, play } \\
\text { areas for children." }\end{array}$ & Agree if used \\
\hline 6 & "It will be more useful." & Disagree because \\
\hline 7 & "For sports and other outdoor activities." & it's uncomfortable \\
\hline 8 & "To be well maintained and useful." & Agreed \\
\hline 9 & $\begin{array}{l}\text { "Do not want to use because there are many dense } \\
\text { bushes." }\end{array}$ & Agree if maintained \\
\hline 10 & $\begin{array}{l}\text { "The flower garden is child-friendly, so there will } \\
\text { be more greening in the environment and pollution- } \\
\text { free }\end{array}$ & Agree if maintained \\
\hline 11 & $\begin{array}{l}\text { "Can be used for various purposes ..., for various } \\
\text { activities ... so that wild animals do not nest ..." }\end{array}$ & Agreed \\
\hline
\end{tabular}


Table 2. The resident agreements in filling Space in settlements (continued)

\begin{tabular}{|c|c|c|}
\hline Residents & Expectations/wishes of residents & $\begin{array}{c}\text { Agreement for } \\
\text { utilization }\end{array}$ \\
\hline 12 & $\begin{array}{l}\text { "To be more useful for the surrounding } \\
\text { environment." }\end{array}$ & Agree if used \\
\hline 13 & "So that it is more useful than being left neglected." & $\begin{array}{l}\text { Agree if used } \\
\text { I'm afraid I have to } \\
\text { disagree because it } \\
\text { is not maintained }\end{array}$ \\
\hline 14 & "Minimal Jogging" & Disagree \\
\hline 15 & "Can be used for sports activities, parks, living & Agree if used \\
\hline 16 & pharmacies, and others & Agree if used \\
\hline
\end{tabular}

The following are several types of utilization of free Space that residents expect, where one respondent expects several uses are a live pharmacy, vegetable plants, mosque/prayer room, children's park/playground, recreation areas, gardening, place of business, sports facilities, parking for vehicles.

Vehicle. Of the 16 respondents, most of them 7 wanted to use the space as a living pharmacy. In comparison, four respondents wanted to use the space as a park or children's playground, and some of the other respondents wanted to use the space as a place for business, sports, gardening and a parking lot.

The following are activities / unwanted uses of the Space around the house:

1. Utilization for personal gain, especially that is detrimental to others.

2. The gathering place for many people, especially the gathering place that is not useful.

3. A place to store used goods, piles of items that are no longer used, so the view and cleanliness are disturbed.

4. Dangdut orchestra.

5. Made a place that is not by the function it should be or privatized.

6. The place of activity is despicable / violates the law.

7. Coffee shops, because it will cause cigarette smoke pollution.

8. As a place to keep animals/animal cages (such as poultry and goats) which can cause foul odours.

9. Landfills, because they will smell and spoil the beauty.

10. Place of business.

\section{The attitude of residents towards Space in informal settlements}

The attitude of the occupants towards Space in non-formal settlements that have not been utilized is that most residents do not object to the existence of Space, as one occupant said, "it is not disturbed, because it has no effect". However, some object if the Space is not used, as he expressed "for parks or sports facilities so that they do not appear empty". The sentence "so as not to appear empty" shows the respondent's attitude who prefers if the available free space can be used. The mood of the occupants towards the Space in non-formal settlements that have been used for 
activities as the results of the interview, all respondents agreed and liked the form of exercise that had been carried out in empty spaces, as the opinion of one respondent regarding the vacant land used as a night market "very supportive by agreement do not litter". Then the other residents also said, "... interesting enough ..". The word "attractive enough" indicates that the respondent agrees and is not disturbed or objectionable if the vacant lot near his house is used as a night market.

The residents' expectation of Space in non-formal settlements is that they hope that the empty spaces around their house can be used as a garden, as stated by one respondent, "... the garden is cool". Then one respondent said that the desired activity was a soccer field as he expressed "soccer match activity because people like to play football". The occupants around the empty room also said their objection if the Space around his residence was used for garbage disposal and playing with firecrackers, as stated by one of the residents "good (used) ... as long as it is not for garbage disposal", and another occupant said ".... the place is dirty". The following activities are expected by residents to be carried out in the space around their residence (i) Garden, (ii) Football field, (iii) Night market, (iv) Sports facilities. Meanwhile, the unwanted activity by the occupants in the vicinity of the space around the place of their residence is used for (i) Garbage dump, (ii) A firecracker play area.

\section{How residents and residents fill empty spaces in settlements}

Several open spaces in formal and informal settlements have been used for temporary and permanent activities. The Space under the sutet lines is partially used by a family in the Arcadia 5 cluster for raising livestock and gardening.
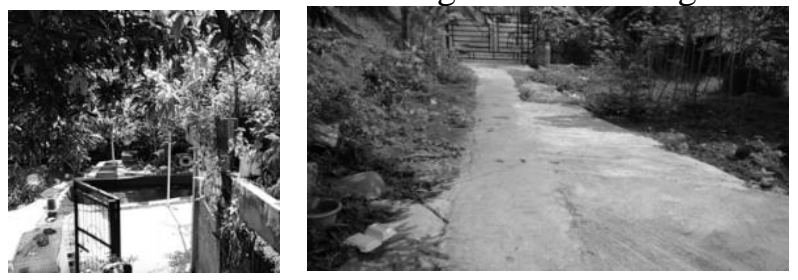

Figure 3. Empty Space beneath the Fenced Sutet, Arcadia cluster Source: Researcher, 2021

Figure 3 (left) shows the access fence from the Arcadia 5 cluster, while Figure 3 (right) shows the exit fence towards the Space under the untapped silk network towards the arcadia cluster neighbourhood road. Figure 4 shows the form of utilization of Space informal settlements for permanent fish farming.
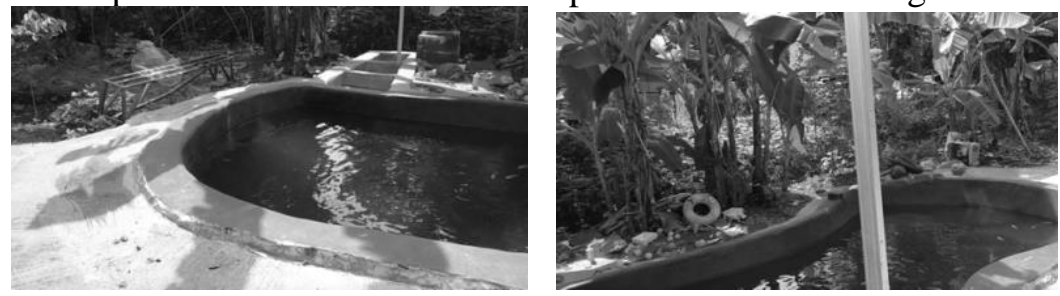

Figure 4. The Space under the silk is Utilized for Fish Farming, Arcadia cluster Source: Researcher, 2021 

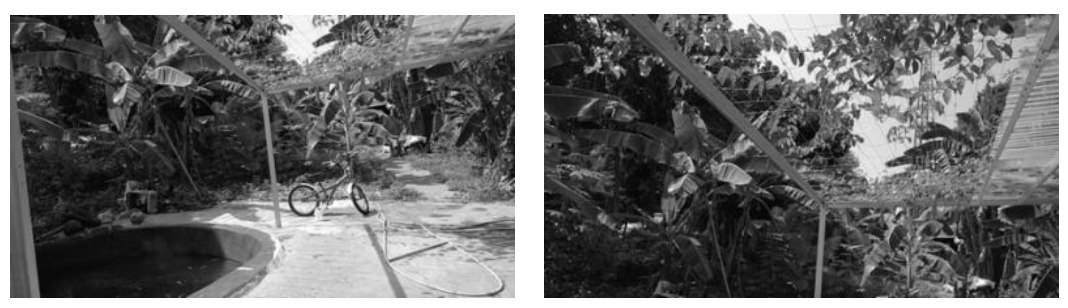

Figure 5. The Space in the Arcadia cluster under the sutet lines for Banana Garden, Pare Plants and others

Source: Researcher, 2021

Figure 5 shows the land under the silk network; besides raising fish, it is also used for (left) growing banana plants and (right) bitter melon plants. Besides that, a shelter is also built permanently on the edge of the pool, which is used as a shelter and resting for a while.

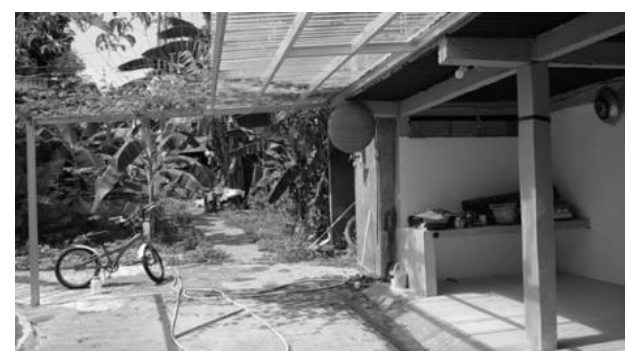

Figure 6. Empty Space in the Arcadia Cluster Below Sutet lines for Pare Plants and Shelters Source: Researcher, 2021

Fish ponds, guardrails and shelters were made at the personal expense of one of the residents of the Arcadia cluster settlement. The reason the residents built this is so that empty land is more beneficial. Besides, the land is also used to store animal cages, as shown in Figure 7.

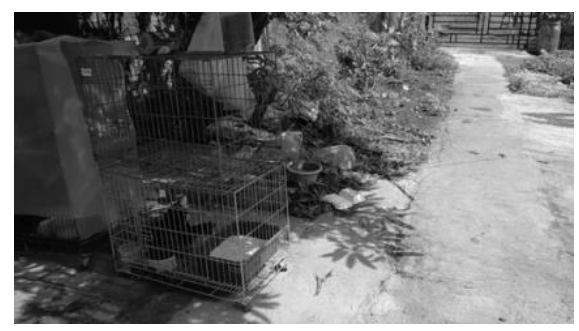

Figure 7. Empty Space in the Arcadia Cluster Below Sutet lines to put the cat cage Source: Researcher, 2021 
Empty houses and yards are both in the Arcadia and Orchid clusters; some are used for activities, but vacant homes and yards are not used. Figure 8 shows an open house yard used as a place to park cars in turn. Besides that, it is also used as a children's play area and a gathering place at certain times, for example, grilling fish during the new year or grilling satay during Eid al-Adha.

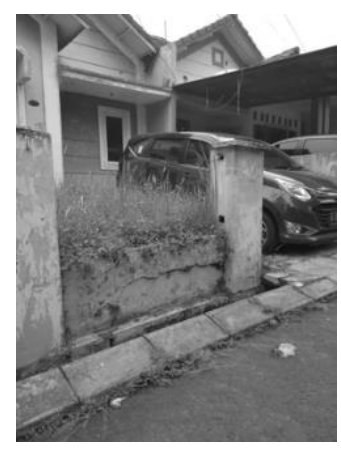

Figure 8. Empty Yard for Car Parking Source: Researcher, 2021

Around the building or on the edge of the park, there are empty spaces of minimal size, which are then used, like the Space around the house just above the gutter used for gardening. Then the open space on the side of the garden is used to place and temporarily accommodate the leaf litter. Then also around the park is used to put garden chairs. Figure 9 shows the Space above the gutter in front of one of the residents who is used as a vegetable plant either by hydroponics or planted in pots. Figure 10 shows the space on the garden's side, which the residents use to place the leaf rubbish temporarily.

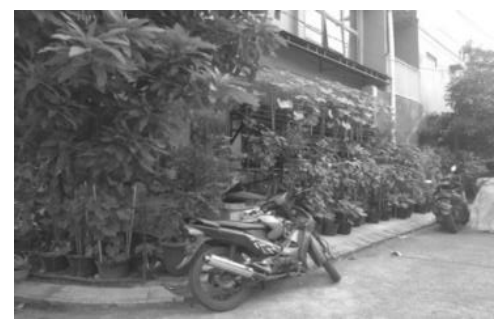

Figure 9. Empty Space above ditch for growing hydroponic vegetables and live pharmacy on the Orchid cluster Source: Researcher, 2021 


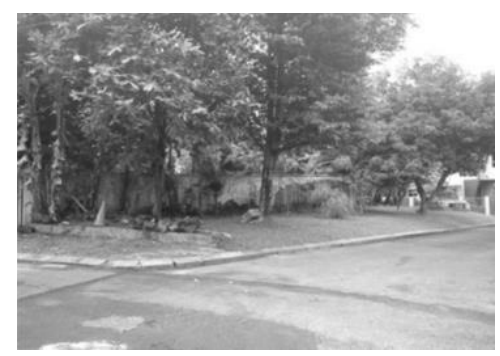

Figure 10. A space on the side of the garden as a place to collect leaf trash in the Arcadia 5 cluster

Source: Researcher, 2021

The surrounding residents more often use the Space in the road space that is rarely passed by vehicles just to turn around. Therefore this Space can be called Space because it is seldom used. During its development, this road space was then used by residents as a Badminton field. However, even this field is rarely used. Figure 21 above is a vacant lot that is routinely used once a week as a night market. Besides, the vacant land is also used by the surrounding residents for a sports field.

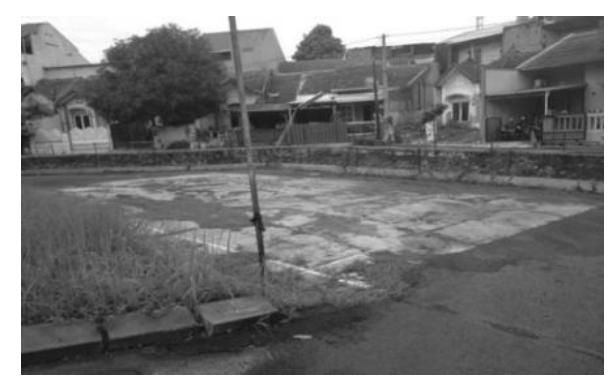

Figure 11. Badminton court in the Arcadia 5 cluster Source: Researcher, 2021

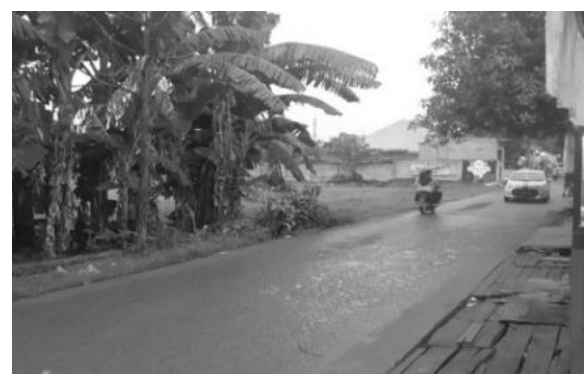

Figure 11. The field in the Ticketing Udik settlement Source: Researcher, 2021 
Currently, residents of formal settlements have used several empty spaces for things that are especially beneficial to their users, such as fish ponds, gardens, living pharmacies, sports venues, car parks. these empty spaces are spaces belonging to housing developers, private property, and public land. For example, the area used as a fish pond is the land under a silk network that is used by an individual, namely one of the residents of the settlement. Most of the surrounding residents agree and agree on the construction of this fish pond. Meanwhile, the garden and living pharmacy is public land that is used by one of the residents, which are directly adjacent to the empty space. All respondents who live in the vicinity of this empty space agree and agree on the use of the empty space as a place for gardening and a living pharmacy. This is also because individuals who use this empty space as gardens and living pharmacies allow and give freedom to all cluster residents to enjoy the produce of the garden and the live pharmacy they plant. The vacant space, which is used as a parking space for vehicles, is used by individual residents of the settlement in turn. This has received support and approval from residents because residents who have more than 1 car can use it so that the road body is not widely used as a vehicle parking lot. The vacant space used by residents as a sports field is based on the results of consultation and agreement Between residents and with the RT and RW as neighborhood administrators. Although in the end this sports field is rare and seldom used for sports anymore. A children's park and playground are facilities provided by housing developers. However, residents and neighborhood administrators took advantage of a certain empty side of the park for a basketball court. The green open space has been built by the developer but looks empty and does not have play facilities, as well as additional children's play equipment, trees, and a sitting room. The use of the park as a children's play area and sports field is based on an agreement between the cluster residents and the environmental committee.

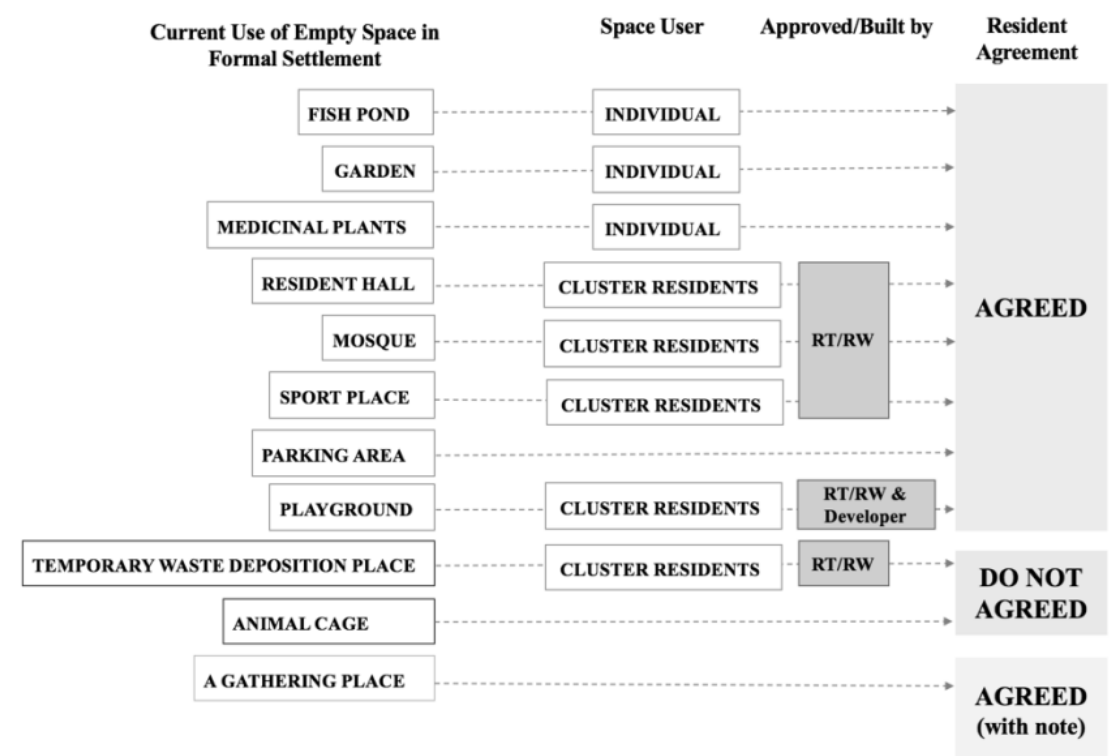

Figure 12. Formal settlement residents' agreement to fill empty spaces Source: Researcher, 2021 
Currently, residents and residents around non-formal settlements have used some of the empty spaces for useful things, namely the night market, sports venues, gardens and places of business. These empty spaces are private spaces both in settlements and along roads. For example, the vacant space used as a night market is privately owned land, which is leased to the night market organizer with the permission of the local $\mathrm{rt}$ management. The residents feel the benefit of the night market because it is a place for the residents to do business. therefore, the residents agreed on the night market as an activity in an empty space.

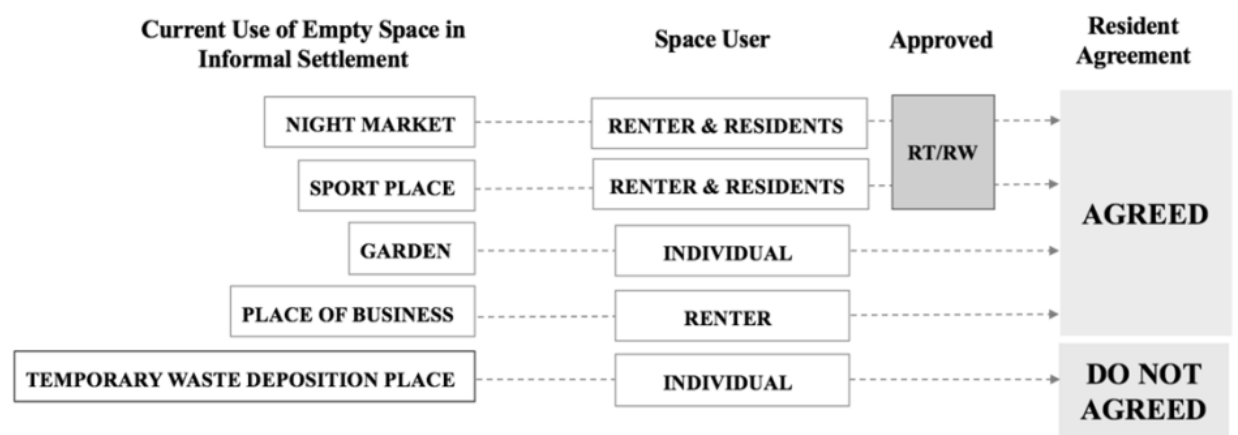

Figure 13. Informal settlement residents' agreement to fill empty spaces Source: Researcher, 2021

Apart from being a night market, empty spaces are also used by residents as a place to exercise, especially a football field, an activity that has been agreed upon by the residents. Of the several uses of empty space that were agreed upon by residents, there was one use of empty space that was not agreed upon by most residents of the settlements but was still carried out by individuals, namely a small proportion of residents who live around the empty space. The empty space that was not agreed upon was the use of the empty space on the side of the garden on the side of the road as a place to collect garbage.

\section{CONCLUSIONS}

Based on the results of observations and interviews, it can be concluded that most residents agree that empty spaces in settlements should not be left open for too long but can be used for valuable things while maintaining public interests, not harming others, not disturbing others, positive and permanent activities. Keep the environment clean.

The form of the agreement is indicated by the following:

1. Most of the residents object to and disagree with the Space that is idle for too long. This is characterised by the attitude of the occupants around the Space. They feel uncomfortable seeing the unkempt and dirty Space and worry that it will become a nesting place for wild animals. 
2. The attitude of the occupants towards the use of empty spaces near their house by several other residents shows that they do not mind, especially those that have been used as vegetable cultivation, living pharmacies and children's playgrounds. However, residents show an objection if the use of the Space disturbs the comfort of the surrounding residents, such as a place to keep animals/animal cages, a place for business and a place for garbage disposal.

3. Residents hope that empty spaces in settlements can be used permanently or temporarily as a living pharmacy, vegetable cultivation, mosques/prayer rooms, children's playgrounds, gardening, business premises, sports facilities and vehicle parking lots.

Forms of the utilization of Space in settlements, both formal and non-formal housing by residents of premises, namely as a place to raise fish, place animal cages, plant fruit and vegetable gardens, park vehicles, play areas for children, place temporary leaf trash, sports fields night market.

\section{ACKNOWLEDGMENT}

The Research Center Mercu Buana University supported this research. We want to express our enormous gratitude to the Research Center Mercu Buana University team for their provided various facilities to complete this research.

\section{REFERENCES}

Akcabozan, A. \& Demir, Y. (2015) A Comparative Parametric Evaluation of Informal and Formal Housing: Maltepe/Istanbul Case Study, Architecture and Urban Planning

Atmodiwirjo, P. \& Yatmo, Y. A. (2018) Editorial: Interiority as Relations, Interiority Vol 1 (2) pp 87-90

Cheon, E. \& Su, N. M. (2018) The Value of Empty Space for Design, Proceedings of the ACM Conference on Human Factors in Computing Systems paper 49

Creswell, J. W. (2016) Research Design: Pendekatan Metode Kualitatif, Kuantitatif dan Campuran, Yogyakarta: Pustaka Pelajar

Harjono, D. K. (2016) Hukum Properti. Jakarta: Pusat Pengembangan Hukum dan Bisnis Indonesia (PPHBI)

Helmstad, G. (1999) Understanding of Understanding: An Inquiry Concerning Experiential Conditions for Developmental Learning, Goteborgs Studies in Educational Science 134, Goteborg: Acta Universitatis Gothoburgensis

Hoffner, Y. \& Field, S. (2005) Transforming agreements into contracts, International Journal of Cooperative Information Systems Vol. 14 (2-3) pp 217-244

Johnson, H. M. (1999) Sociology: A Systematic Introduction. London: Taylor \& Francis Ltd

List, C. (2002) Two Concepts of Agreement, The Good Society 
Luck, R. (2014) Seeing Architecture in Action: Designing, Evoking and Depicting Space and Form in Embodied Interaction, International Journal of Design Creativity and Innovation Vol 2 (3) pp 165-181

Sengke, M. M. C. \& Mustikawati, T. (2019) The Visual Mechanisms of Seeing in Experiencing the Interior, Interiority Vol 2 (2) pp 213-229

Setiawan, H. B. 2014. Arsitektur, Lingkungan dan Perilaku. Yogyakarta: Gadjah Mada University Press.

Shea, M. \& Ceprano, (M. 2017) Reading with Understanding: A Global Expectation, Journal of Inquiry \& Action in Education Vol 9 (1) pp 48-68

Pallasmaa, J. (2012) The Eyes of The Skin: Architecture and The Senses, West Sussex: John Wiley \& Sons

Pluta, A. (2019) The Importance of Empty Spaces in Cities and A Proposed Set of Tools to Support Their Use, Biblioteka Regionalisty Regional Journal NR 19

Salerno, R. (2011) Filling in Gaps in the Urban Landscape with a patchwork of Open Space, A Proposal for the Dispersed City, EFLA Regional Congress of Landscape: Mind the Gap Landscape for A New Era.

Setiawan, H. B. (2014) Arsitektur, Lingkungan dan Perilaku. Yogyakarta: Gadjah Mada University Press.

Soyinka, O. and Siu, K. W. M. (2017) Investigating Informal Settlement and Infrastructure Adequacy for Future Resilient Urban Center in Hongkong, SAR, Procedia Engineering 198 pp. 84-98

Stanek, L. (2011) Henry Lefebvre on Space: Architecture, Urban Research, and the Production of Theory, University of Minnesota Press Minneapolis

Winter, G \& Kamau, C. K. (2019) Model Clauses for Mutually Agreed Terms on Access to Genetic Resources and Benefit Sharing, Lead Law Environment and Development Journal Vol 12/1 pp. 20-33

https://kbbi.web.id/sepakat

https://www.liputan6.com/bisnis/read/4089849/pupr-program-satu-juta-rumah-

lampaui-target : Diakses pada tanggal 31 Oktober 2019 pukul 22.10 WIB 